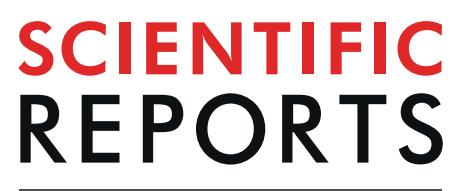

natureresearch

\title{
Polyoxometalate chemistry at volcanoes: discovery of a novel class of polyoxocuprate nanoclusters in fumarolic minerals
}

\author{
S. N. Britvin ${ }^{1,2}$, I. V. Pekov ${ }^{3}$, V. O. Yapaskurt ${ }^{3}$, N. N. Koshlyakova ${ }^{3}$, J. Göttlicher ${ }^{4}$, \\ S. V. Krivovichev ${ }^{1,2^{*}}$, A. G. Turchkova ${ }^{3}$ \& E. G. Sidorov ${ }^{5}$
}

Polyoxometalate (POM) chemistry is an important avenue of comprehensive chemical research, due to the broad chemical, topological and structural variations of multinuclear polyoxoanions that result in advanced functionality of their derivatives. The majority of compounds in the polyoxometalate kingdom are synthesized under laboratory conditions. However, Nature has its own labs with the conditions often unconceivable to the mankind. The striking example of such a unique environment is volcanic fumaroles - the natural factories of gas-transport synthesis. We herein report on the discovery of a novel class of complex polyoxocuprates grown in the hot active fumaroles of the Tolbachik volcano at the Kamchatka Peninsula, Russia. The cuboctahedral nanoclusters $\left\{\left[\mathrm{MCu}_{12} \mathrm{O}_{8}\right]\left(\mathrm{AsO}_{4}\right)_{8}\right\}$ are stabilized by the core $\mathrm{Fe}(\mathrm{III})$ or $\mathrm{Ti}(\mathrm{IV})$ cations residing in the unique cubic coordination. The nanoclusters are uniformly dispersed over the anion- and cation-deficient $\mathrm{NaCl}$ matrix. Our discovery might have promising implications for synthetic chemistry, indicating the possibility of preparation of complex polyoxocuprates by chemical vapor transport (CVT) techniques that emulate formation of minerals in high-temperature volcanic fumaroles.

Polyoxometalates (POMs) constitute a large group of materials with discrete metal-anion clusters of various shapes and sizes ${ }^{1-3}$. Traditionally, POMs were associated with $d$-block metals in high oxidation states $\left(\mathrm{V}^{5+}, \mathrm{Nb}^{5+}\right.$, $\mathrm{Ta}^{5+}, \mathrm{Mo}^{6+}$ and $\left.\mathrm{W}^{6+}\right)$, but recent studies extended the field to other elements such as actinides ${ }^{4}$ and noble met$\mathrm{als}^{5}$. In 1990, Achim Müller and co-workers ${ }^{6}$ introduced the term 'polyoxocuprates' (POCus) to identify clusters formed by polymerization of $\mathrm{Cu}$ coordination polyhedra, previously reported for synthetic inorganic compounds such as $\mathrm{Ba}_{44} \mathrm{Cu}_{45} \mathrm{O}_{87} \mathrm{Cl}_{4}$ and $\mathrm{Ba}_{88} \mathrm{Cu}_{88} \mathrm{O}_{175} \mathrm{Br}_{2}{ }^{7}$. The POCus have been intensively investigated recently as reviewed by Kondinski and Monakhov $^{8}$, due to their potential applications in catalysis, molecular magnetism and superconductivity. Usually POCus are obtained by crystallization from aqueous solutions at $\mathrm{pH}$ values between 3.5 and 7 via polymerization of $\mathrm{Cu}(\mathrm{OH})_{4}$ planar-square units.

Natural crystalline POMs have been under extensive investigation over the last ten years and are known for $\mathrm{Mo}^{9}, \mathrm{~V}^{10-12}$, and $\mathrm{Nb}^{13}$. Besides, uranyl carbonate nanoscale clusters have been reported for $\mathrm{U}^{6+}$ carbonate minerals such as ewingite, $\mathrm{Ca}_{8} \mathrm{Mg}_{8}\left(\mathrm{UO}_{2}\right)_{24}\left(\mathrm{CO}_{3}\right)_{30} \mathrm{O}_{4}(\mathrm{OH})_{12}\left(\mathrm{H}_{2} \mathrm{O}\right)_{138}{ }^{14}$, and paddlewheelite, $\mathrm{Ca}_{5} \mathrm{MgCu}_{2}\left(\mathrm{UO}_{2}\right)_{4}\left(\mathrm{CO}_{3}\right)_{12}\left(\mathrm{H}_{2} \mathrm{O}\right)_{33}{ }^{15}$. Other examples are two natural arsenates, bouazzerite ${ }^{16}, \mathrm{Bi}_{6}(\mathrm{Mg}, \mathrm{Co})_{11} \mathrm{Fe}_{14}$ $\left(\mathrm{AsO}_{4}\right)_{18} \mathrm{O}_{12}(\mathrm{OH})_{4}\left(\mathrm{H}_{2} \mathrm{O}\right)_{86}$, and whitecapsite ${ }^{17}, \mathrm{H}_{16} \mathrm{Sb}^{3+}{ }_{6} \mathrm{Fe}^{2+}{ }_{5} \mathrm{Fe}^{3+}{ }_{14}\left(\mathrm{AsO}_{4}\right)_{18} \mathrm{O}_{16}\left(\mathrm{H}_{2} \mathrm{O}\right)_{120}$, which are based upon heptanuclear iron-oxide-arsenate nanoclusters. We note that discrete $\mathrm{Cu}-\mathrm{OH}$ clusters have also been reported in minerals, e.g., the $\left[\mathrm{Cu}_{12}(\mathrm{OH})_{24}\right]$ clusters in zeolite tschörtnerite ${ }^{18}, \mathrm{Ca}_{4}\left(\mathrm{Ca}, \mathrm{Sr}, \mathrm{K}, \mathrm{Ba}_{3} \mathrm{Cu}_{3}\left[\mathrm{Al}_{3} \mathrm{Si}_{3} \mathrm{O}_{12}\right]_{4}(\mathrm{OH})_{8} \cdot n \mathrm{H}_{2} \mathrm{O}\right.$, the $\left[\mathrm{Cu}_{24}(\mathrm{OH})_{48}\right]$ clusters in boleite ${ }^{19}, \mathrm{KPb}_{26} \mathrm{Ag}_{9} \mathrm{Cu}_{24}(\mathrm{OH})_{48} \mathrm{Cl}_{62}$, and pseudoboleite ${ }^{20}, \mathrm{~Pb}_{31} \mathrm{Cu}_{24} \mathrm{Cl}_{62}(\mathrm{OH})_{48}$, and the $\left[\mathrm{Cu}_{20}(\mathrm{OH})_{40}\right]$ clusters in cumengeite ${ }^{21}, \mathrm{~Pb}_{21} \mathrm{Cu}_{20} \mathrm{Cl}_{42}(\mathrm{OH})_{40} \cdot 6 \mathrm{H}_{2} \mathrm{O}$. It is noteworthy that all the reported

${ }^{1}$ Department of Crystallography, Institute of Earth Sciences, St. Petersburg State University, University Embankment 7/9, 199034, St Petersburg, Russia. ${ }^{2}$ Kola Science Center of Russian Academy of Sciences, Fersman Str. 14, 184200, Apatity, Russia. ${ }^{3}$ Faculty of Geology, Moscow State University, Vorobievy Gory, 119991, Moscow, Russia. ${ }^{4}$ Karlsruhe Institute of Technology, Institute for Synchrotron Radiation, Hermann-von-Helmholtz-Platz 1, D-, 76344, Eggenstein-Leopoldshafen, Germany. ${ }^{5}$ Institute of Volcanology and Seismology, Far Eastern Branch of the Russian Academy of Sciences, Piip Boulevard 9, 683006, Petropavlovsk-Kamchatsky, Russia. *email: s.krivovichev@spbu.ru 

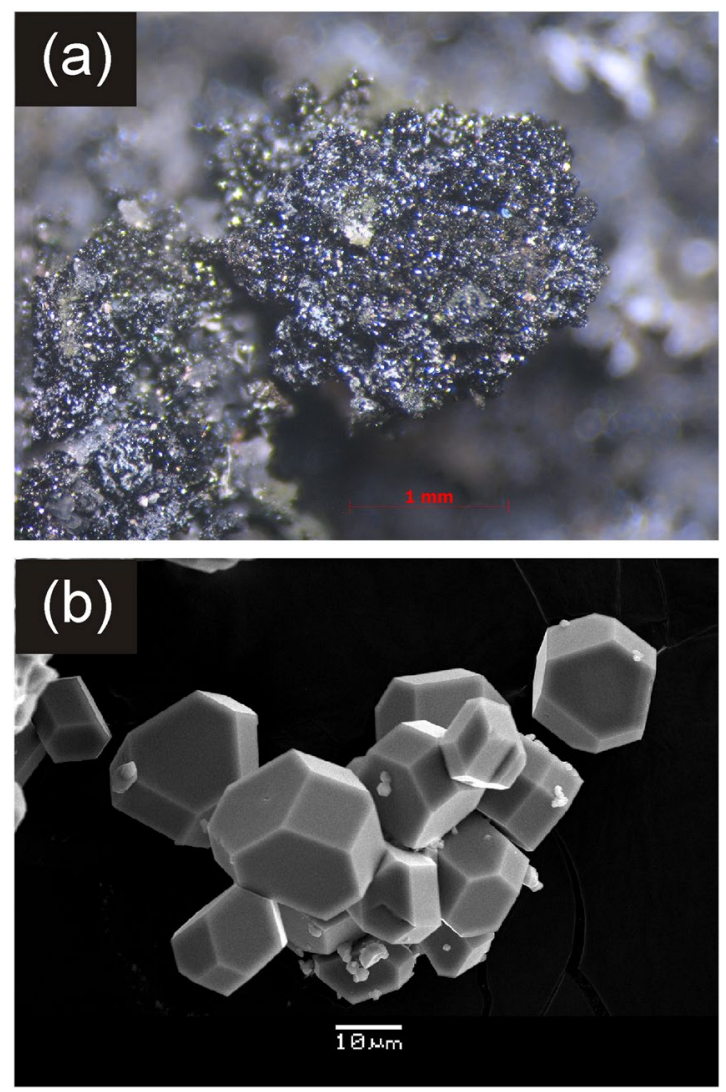

Figure 1. Crystalline crusts of greenish black arsmirandite (a) and scanning electron microscopy (SEM) image of clusters of arsmirandite crystals (b).

occurrences of POMs in nature have been restricted to low-temperature aquiferous systems, namely oxidation zones of ore deposits $\left(<50-70^{\circ} \mathrm{C}\right)$ or last-stage hydrothermal environments $\left(<150-200^{\circ} \mathrm{C}\right)$.

Volcanic fumaroles are unique in both physical and chemical (geochemical) aspects. In fumarolic systems minerals either directly precipitate from volcanic gases as sublimates or form as a result of their interactions with host rocks. Among fumarolic minerals, copper-based anhydrous mineral phases constitute one of the most rich and diverse groups. The explosion of recent discoveries of $\mathrm{Cu}^{2+}$ fumarolic minerals is related to the Tolbachik volcano at Kamchatka Peninsula, Russia. The $\mathrm{Cu}$ mineralization at Tolbachik was reviewed by Pekov et al. ${ }^{22}$, and the most recent descriptions of new mineral species can be found in refs. ${ }^{23-26}$. The $\mathrm{Cu}$ minerals found in Tolbachik fumaroles are remarkable by their structural architecture, which frequently contain polymeric $\mathrm{Cu}$-oxo units based upon oxocentered $\mathrm{OCu}_{4}$ tetrahedra. These tetrahedra may polymerize to form structural units of different dimensionalities ${ }^{27,28}$. Herein we report two novel halide-arsenate mineral species, arsmirandite and lehmannite, found at Tolbachik that represent the first example of natural POCus and provide a unique insight into the ability of $\mathrm{Cu}^{2+}$ cations to form discrete nanoclusters in anhydrous natural environments. Our discovery also provide some important clues for the synthesis and chemical tuning of cubic POCus for further studies of their physical and chemical properties.

\section{Results}

Two new mineral species, arsmirandite and lehmannite, have been found in the active Arsenatnaya fumarole ${ }^{29,30}$ located at the Second scoria cone of the Northern Breakthrough of the Great Tolbachik Fissure Eruption 1975-1976, Tolbachik volcano, Kamchatka Peninsula, Far-Eastern Region, Russia $\left(55^{\circ} 41^{\prime} \mathrm{N} 160^{\circ} 14^{\prime} \mathrm{E}, 1200 \mathrm{~m}\right.$ asl). The mineral assemblages encasing these halide-arsenates were formed in the temperature range between 500 and $700{ }^{\circ} \mathrm{C}^{22,30}$ and were located inside the fumarole. The detailed mineralogical description of the minerals will be given elsewhere. Polyoxocuprates occur as aggregates of greyish-green well-shaped crystals resembling rhombic dodecahedra (Fig. 1) that could easily be separated from the surrounding matrix. The chemical composition of arsmirandite and lehmannite were determined using electron-microprobe analysis (Table S0). The empirical formula of arsmirandite, calculated on the basis of 45 anions $(\mathrm{O}+\mathrm{Cl}) p f u$, is: $\mathrm{Na}_{17.06} \mathrm{~K}_{0.51} \mathrm{Ca}_{0.06} \mathrm{~Pb}_{0.08} \mathrm{Mg}_{0.11} \mathrm{Mn}_{0.01} \mathrm{Cu}_{11.73} \mathrm{Zn}_{0.08} \mathrm{Al}_{0.02} \mathrm{Fe}^{3+}{ }_{0.92} \mathrm{Ti}_{0.10}\left(\mathrm{As}_{7.91} \mathrm{~S}_{0.08} \mathrm{P}_{0.03} \mathrm{Si}_{0.02} \mathrm{~V}_{0.01}\right)_{\Sigma 8.05} \mathrm{O}_{40.23} \mathrm{Cl}_{4.77}$. The empirical formula of lehmannite, calculated on the basis of the sum of tetrahedrally coordinated components $(\mathrm{As}+\mathrm{P}+\mathrm{S}+\mathrm{Si})=8 \mathrm{apfu}$, is: $\mathrm{Na}_{17.92} \mathrm{~K}_{0.18} \mathrm{Ca}_{0.24} \mathrm{Cu}_{11.59} \mathrm{Fe}^{3+}{ }_{0.21} \mathrm{Ti}_{0.85} \mathrm{Sn}_{0.11}\left(\mathrm{As}_{7.74} \mathrm{~S}_{0.14} \mathrm{P}_{0.09} \mathrm{Si}_{0.03}\right)_{\Sigma 8} \mathrm{O}_{40.10} \mathrm{~F}_{0.75} \mathrm{Cl}_{5.42}$. The idealized chemical formulae for arsmirandite and lehmannite were determined as $\mathrm{Na}_{18} \mathrm{Cu}_{12}{ }^{2+} \mathrm{Fe}^{3+} \mathrm{O}_{8}\left(\mathrm{AsO}_{4}\right)_{8} \mathrm{Cl}_{5}$ and $\mathrm{Na}_{18} \mathrm{Cu}_{12}{ }^{2+} \mathrm{Ti}^{4+} \mathrm{O}_{8}\left(\mathrm{AsO}_{4}\right)_{8} \mathrm{FCl}_{5}$, respectively. 
(a)

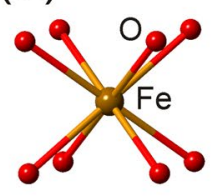

(d)

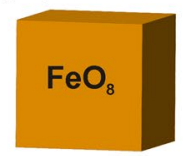

(b)

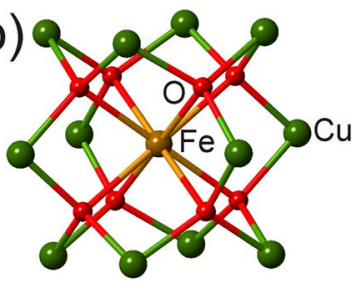

(e)

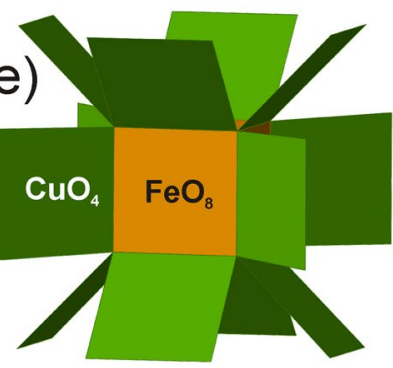

(g)

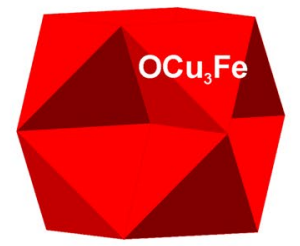

(c)

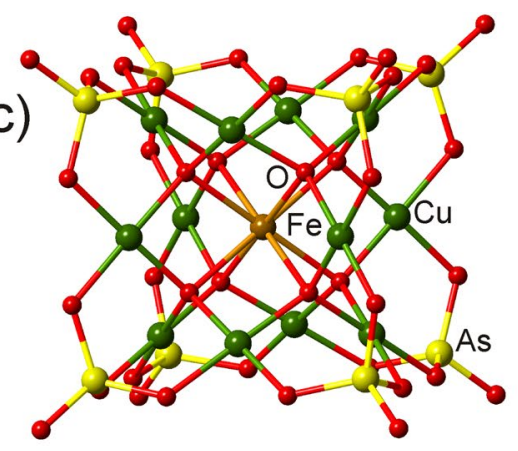

(f)

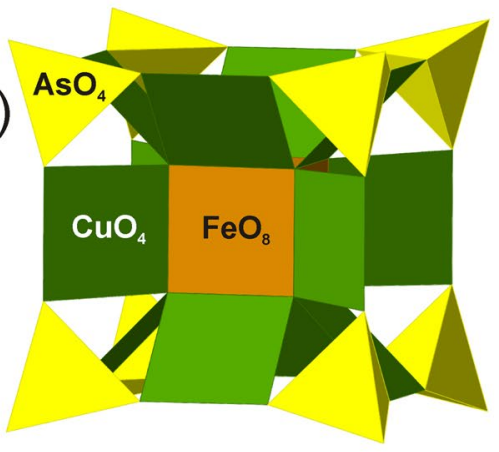

(h)

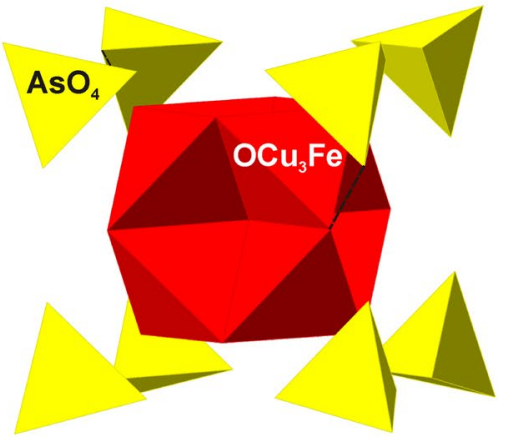

Figure 2. The structure of the polyoxocuprate nanoclusters in arsmirandite and lehmannite shown in balland-stick (a-c) and polyhedral (cation-centered (d-f) and combined anion- and cation-centered (g,h)) representations (exemplified by arsmirandite).

The crystal structures of arsmirandite and lehmannite (Tables S1-S7) are very similar, yet not identical. From the structural point of view, they are quite unusual and unique. The basic structural unit in both structures is a novel nanoscale $(\sim 1.5 \mathrm{~nm}$ across $)$ polyoxocuprate cluster with the composition $\left\{\left[M \mathrm{Cu}_{12} \mathrm{O}_{8}\right]\left(\mathrm{AsO}_{4}\right)_{8}\right\}\left(M=\mathrm{Fe}^{3+}\right.$ and $\mathrm{Ti}^{4+}$, for arsmirandite and lehmannite, respectively) shown in Fig. 2. The most peculiar feature of the nanocluster is the presence of $\mathrm{Fe}^{3+}$ (arsmirandite) or $\mathrm{Ti}^{4+}$ (lehmannite; the tetravalent state of Ti confirmed by XANES spectroscopy (Fig. S3)) in a cubic coordination (Fig. 2a): the central unit of the nanocluster represents the slightly distorted $\left(\mathrm{MO}_{8}\right)$ cube (Fig. 2a,d). The cubic coordination of $\mathrm{Fe}(\mathrm{III})$ and $\mathrm{Ti}(\mathrm{IV})$ has not been encountered so far in natural minerals, though several examples are known for synthetic compounds ${ }^{31-34}$. Each $\mathrm{O}$ atom of the $\left(\mathrm{MO}_{8}\right)$ configuration is further coordinated by three $\mathrm{Cu}^{2+}$ cations (Fig. 2b) that have square-planar geometry by $\mathrm{O}$ atoms of the $\left(\mathrm{AsO}_{4}\right)$ groups (Fig. 2c,e,f). The metal-oxide core of the nanocluster can also be represented in terms of oxocentered $\left(\mathrm{OCu}_{3} M\right)$ tetrahedra ${ }^{27,28}$ that form an eightfold unit (Fig. 2g), which can be considered as a fragment of the crystal structure of fluorite, if the latter is described as a framework of $\left(\mathrm{FCa}_{4}\right)$ tetrahedra. The $\left[\mathrm{O}_{8} \mathrm{MCu}_{12}\right]$ core formed by eight oxocentered tetrahedra is surrounded by eight $\mathrm{AsO}_{4}$ tetrahedra that are in the face-to-face orientation relative to the $\left(\mathrm{OCu}_{3} M\right)$ tetrahedra ${ }^{35}$ (Fig. $\left.2 \mathrm{~h}\right)$. The cubic nanoclusters are negatively charged and are surrounded by an array of $\mathrm{Na}^{+}$cations and $X^{-}$anions $(X=\mathrm{F}, \mathrm{Cl})$ (Fig. 3), which requires further remark. The analysis of the Na array in arsmirandite and lehmannite (Figs. S1 and S2) shows that it is in fact a highly deficient face-centered cubic $(f c c)$ lattice as observed, e.g. in the crystal structure of halite, $\mathrm{NaCl}^{36}$. The halite-like cubic pseudo-subcell can be obtained from the true unit cell using the matrix $\left(\frac{1}{2} 00 / 0 \frac{1}{4} 0 / \frac{1}{4} 0 \frac{1}{2}\right)$, i.e. the structures of arsmirandite and lehmannite can be considered as the $2 \times 4 \times 4$ supercell relative to the halite cell. The parameters of the halite-like cubic subcell, e.g., in lehmannite, are: $a_{\text {hal }}=5.418, b_{\text {hal }}=5.273, c_{\text {hal }}=5.279 \AA$, which shows that, realtive to halite, the deficient $\mathrm{Na} f c c$ array is compressed and tetragonally distorted. 
(a)
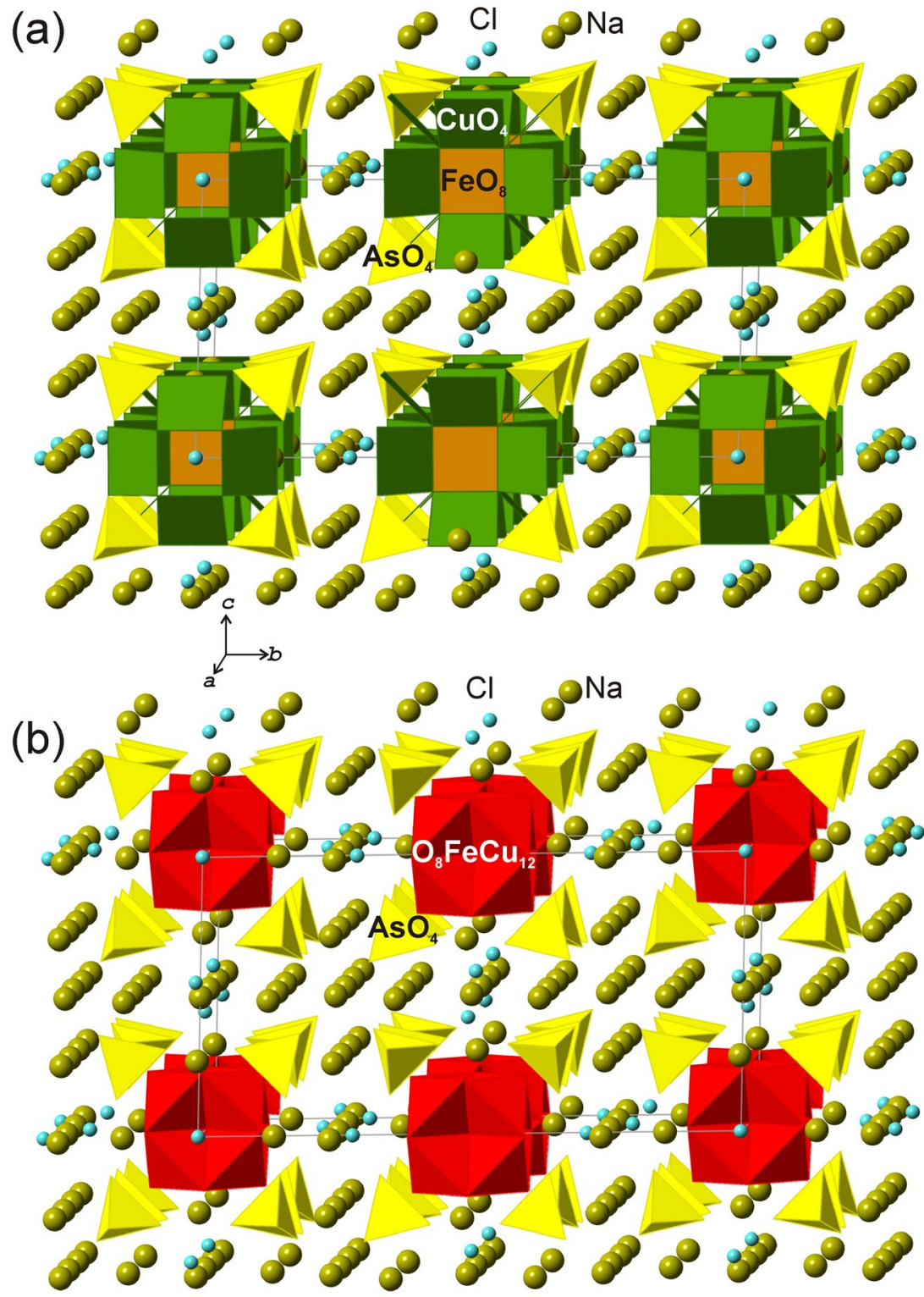

Figure 3. The crystal structure of arsmirandite with nanoclusters shown in cation-centered (a) and combined anion- and cation-centered (b) representations.

\section{Discussion}

The difference between arsmirandite and lehmannite is in the nature of the $M$ cation, which triggers the re-arrangement of the halogen substructure. Since $\mathrm{Fe}^{3+}$ and $\mathrm{Ti}^{4+}$ possess different charges, the $\mathrm{Fe}^{3+}$-for- $\mathrm{Ti}^{4+}$ substitution requires the mechanism of charge compensation, which is achieved via the incorporation of the additional anionic site, $\mathrm{F}$, in lehmannite ( $\mathrm{Ti}^{4+}$ species) relative to arsmirandite (mineral with $\mathrm{Fe}^{3+}$ ). The charge compensation, therefore, is governed by the following substitution scheme:

$$
\mathrm{Fe}^{3+}+\square^{0} \rightarrow \mathrm{Ti}^{4+}+\mathrm{F}^{-},
$$

where the ' $\square$ ' sign stays for vacancy.

In lehmannite, the substitution is realized through the following crystal chemical mechanism. The Cl1 site with the $2 / m$ site symmetry with the coordinates $(1 / 2,1 / 2,0)$ in arsmirandite is shifted along the $a$ axis to the Cl1 site with the $m$ site symmetry (approximate coordinates: $0.53,1 / 2,0$ ) in lehmannite, resulting in the splitting of the Cl1 site into two mutually exclusive sites. The F site with the same $m$ site symmetry is incorporated (approximate coordinates: $0.65,1 / 2,0$ ) into the structure so that the $\mathrm{Cl} 1 \cdots \mathrm{F}$ distance is equal to $c a$. $1.3 \AA$. The short distance precludes the simultaneous occupancy of the $\mathrm{Cl} 1$ and $\mathrm{F}$ sites with the maximum total occupancy $\mathrm{F}_{0.50} \mathrm{Cl}_{0.50}$. Note that the $\mathrm{Cl} 1 \cdots \mathrm{Cl} 1$ distance in disordered configuration is very short $(\sim 0.6 \AA$ in lehmannite), prohibiting more-than-50\% occupancy of the $\mathrm{Cl} 1$ site, whereas the $\mathrm{F} \cdots \mathrm{F}$ distance $(\sim 3.1 \AA)$ allows for the full occupancy of the two F sites assuming that the Cll site is empty. 
In lehmannite, the disordered configuration has the total occupancy $\mathrm{F}_{0.52} \mathrm{Cl}_{0.34 \square 0.16}$ or $\mathrm{F}_{1.04} \mathrm{Cl}_{0.68 \square 0.32}$ per formula unit ( $p f u$ ) with the -1.72 total negative charge. The corresponding occupancy of the $M$ site is calculated as $\mathrm{Ti}^{4+}{ }_{0.69} \mathrm{Fe}^{3+}{ }_{0.28} \mathrm{Sn}^{4+}{ }_{0.03}$ with the total positive charge +3.72 , which provides the formula electroneutrality. The full substitution of $\mathrm{Fe}^{3+}$ by $\mathrm{Ti}^{4+}$ in lehmannite would correspond to the total occupancy of the anionic sites $\mathrm{F}_{0.50} \mathrm{Cl}_{0.50}$ or $\mathrm{F}_{1.00} \mathrm{Cl}_{1.00} p f u$ with the -2 total negative charge.

The crystal chemical formula of arsmirandite determined on the basis of chemical analysis and crystal-structure refinement can be written as $\left(\mathrm{Na}_{17.54} \mathrm{~K}_{0.46}\right)_{\Sigma 18.00}\left(\mathrm{Fe}^{3+}{ }_{0.78} \mathrm{Mg}_{0.11} \mathrm{Ti}_{0.11}\right)_{\Sigma 1.00} \mathrm{Cu}^{2+}{ }_{12}\left(\mathrm{AsO}_{4}\right)_{8} \mathrm{O}_{8} \mathrm{Cl}_{5}$. Note that the incorporation of $\mathrm{Ti}^{4+}$ into the $M$ site is compensated by the coupled substitution of $\mathrm{Fe}^{3+}$ by $\mathrm{Mg}^{2+}$ :

$$
2 \mathrm{Fe}^{3+} \rightarrow \mathrm{Ti}^{4+}+\mathrm{Mg}^{2+} .
$$

The crystal chemical formula of lehmannite can be written as $\left(\mathrm{Na}_{17.62} \mathrm{~K}_{0.38}\right)_{\Sigma 18.00}\left(\mathrm{Ti}^{4+}{ }_{0.69} \mathrm{Fe}^{3+}{ }_{0.28} \mathrm{Sn}^{4+}{ }_{0.03}\right)_{\Sigma 1.00} \mathrm{Cu}^{2+}{ }_{12}$ $\left(\mathrm{AsO}_{4}\right)_{8} \mathrm{O}_{8} \mathrm{Cl}_{4.68} \mathrm{~F}_{1.04}$.

Taking into account the discussion given above, the general formula of the hypothetical arsmirandite-lehmannite series can be written as $\mathrm{Na}_{18}\left(\mathrm{Ti}^{4+}{ }_{1-x} \mathrm{Fe}^{3+}{ }_{x}\right) \mathrm{Cu}_{12}\left(\mathrm{AsO}_{4}\right)_{8} \mathrm{O}_{8} \mathrm{Cl}_{6-x-y} \mathrm{~F}_{y}$. The ideal formula of arsmirandite corresponds to $x=1$ and $y=0$, whereas that of lehmannite requires $x=0$ and $y=1$. Note that $0 \leq x \leq 1$, whereas $0 \leq y \leq 2$. The experimental case of lehmannite corresponds to $x=0.28$ and $y=1.04$. The case $y=2$ corresponds to the full occupancy of the $\mathrm{F}$ site and the complete emptiness of the $\mathrm{Cl} 1$ site and results in the 'theoretical' formula $\mathrm{Na}_{18}\left(\mathrm{Ti}^{4+}{ }_{1-x} \mathrm{Fe}^{3+}{ }_{x}\right) \mathrm{Cu}_{12}\left(\mathrm{AsO}_{4}\right)_{8} \mathrm{O}_{8} \mathrm{Cl}_{4-x} \mathrm{~F}_{2}$. For this formula, $x=1$ results in the formula $\mathrm{Na}_{18} \mathrm{Fe}^{3+} \mathrm{Cu}_{12}\left(\mathrm{AsO}_{4}\right)_{8} \mathrm{O}_{8} \mathrm{Cl}_{3} \mathrm{~F}_{2}$ (hypothetical $\mathrm{F}$-rich analogue of arsmirandite), whereas $x=0$ corresponds to $\mathrm{Na}_{18} \mathrm{Ti}^{4+} \mathrm{Cu}_{12}\left(\mathrm{AsO}_{4}\right)_{8} \mathrm{O}_{8} \mathrm{Cl}_{4} \mathrm{~F}_{2}$ (hypothetical F-rich analogue of lehmannite). These two potentially possible species may occur in F-enriched fumarolic environments.

The metal-oxide $\left[\mathrm{O}_{8} \mathrm{Me}_{13}\right]$ nanoclusters $\left(\mathrm{Me}=\right.$ metal) consisting of eight $\left(\mathrm{OMe}_{4}\right)$ tetrahedra sharing central $\mathrm{Me}$ atom are well-known in synthetic inorganic chemistry. It seems that the first detailed structural report was done for $M e=\mathrm{Pb}^{2+}$ found in the crystal structure of $\mathrm{Pb}_{13} \mathrm{O}_{8}(\mathrm{OH})_{6}\left(\mathrm{NO}_{3}\right)_{4}{ }^{37}$. In this compound, the central 8 -coordinated cation in the nanocluster is $\mathrm{Pb}^{2+}$, which has a stereochemically inactive lone-electron pair, in contrast to twelve peripheral $\mathrm{Pb}^{2+}$ that possess strongly asymmetrical coordination environments. Later Kolitsch and Tillmanns ${ }^{38}$ reported $\mathrm{Pb}_{13} \mathrm{O}_{8}(\mathrm{OH})_{6}\left(\mathrm{NO}_{3}\right)_{4}$ as an anthropogenic compound formed in old mine dumps due to the use of nitrate explosives. The phase $\mathrm{Pb}_{13} \mathrm{O}_{8}(\mathrm{OH})_{6}\left(\mathrm{NO}_{3}\right)_{4}$ forms in the $\mathrm{Pb}\left(\mathrm{NO}_{3}\right)_{2}-\mathrm{NaOH}$ system at $\mathrm{pH}=9-10^{39}$.

In 2008, Chubarova et al. ${ }^{40}$ reported on the synthesis and structure of $\mathrm{Na}_{8}\left\{\left[\mathrm{Pd}_{13} \mathrm{O}_{8}\right]\right.$ $\left.\left(\mathrm{AsO}_{3}(\mathrm{OH})\right)_{6}\left(\mathrm{AsO}_{4}\right)_{2}\right\} \cdot 42 \mathrm{H}_{2} \mathrm{O}$, the compound, which opened up the whole new field of polyoxopalladate chemistry ${ }^{5}$. The crystal structure of this compound is based upon $\left\{\left[\mathrm{Pd}_{13} \mathrm{O}_{8}\right]\left(\mathrm{AsO}_{3}(\mathrm{OH})\right)_{6}\left(\mathrm{AsO}_{4}\right)_{2}\right\}^{8-}$ nanoclusters structurally identical to those found in arsmirandite and lehmannite (which are also arsenates). Later it was found that arsenate groups can be replaced by phosphate ${ }^{41}$ or selenite groups ${ }^{42-44}$. The central $\mathrm{Pd}^{2+}$ cation in the Pd-based 13-nuclear nanoclusters $\left(\mathrm{Fe}^{3+}\right.$ and $\mathrm{Ti}^{4+}$ in arsmirandite and lehmannite, respectively, play the same role as $\mathrm{Pd}^{2+}$

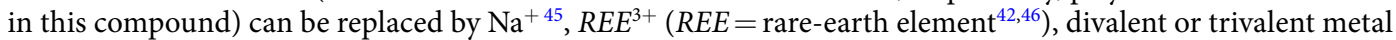
cations $M^{2+}\left(M=\mathrm{Sc}^{3+}, \mathrm{Mn}^{2+}, \mathrm{Fe}^{3+}, \mathrm{Co}^{2+}, \mathrm{Ni}^{2+}, \mathrm{Cu}^{2+}\right.$, or $\left.\mathrm{Zn}^{2+}\right)$, and tetravalent $\mathrm{Sn}^{4+}$ and $\mathrm{Pb}^{4+}$ cations ${ }^{47}$. Very recently, Bhattacharya et al. ${ }^{48}$ reported on the use of the 13-nuclear Pd-based nanoclusters, $\left[\mathrm{Pd}_{13} \mathrm{O}_{8}\left(\mathrm{AsO}_{4}\right)_{8} \mathrm{H}_{6}\right]^{8-}$, incrustated by $\mathrm{Ba}^{2+}$ cations for the construction of novel types of porous metal-organic frameworks. It is remarkable that, in arsmirandite and lehmannite, the role of $\mathrm{Pd}^{2+}$ cations in peripheral metal positions is played by $\mathrm{Cu}^{2+}$ cations, whereas the central cation in the metal-oxide core is either $\mathrm{Fe}^{3+}$ or $\mathrm{Ti}^{4+}$, respectively. The observed stereochemical similarity is due to the similar square planar coordination by $\mathrm{O}^{2-}$ anions specific for both $\mathrm{Pd}^{2+}$ and $\mathrm{Cu}^{2+}$. Our findings indicate the chemical possibility of the family of novel polyoxocuprate clusters with interesting functional properties. Yang and Kort $\mathrm{z}^{5}$ indicate that the Pd nanoclusters are stable in the solid state, solutions (both aqueous and organic) and gases, which allows for their applications in catalysis, nanotechnology, molecular spin qubits and in biology as aqueous-phase macromolecular models.

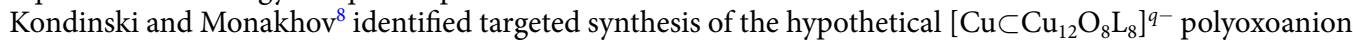
$(\mathrm{L}=$ inorganic or organic ligand, e.g. arsenate, phosphate, selenite, etc.) with two different coordination modes of central and peripheral $\mathrm{Cu}^{2+}$ ions as an interesting challenge for synthetic chemistry of POCus. The discovery of the $\left[M \subset \mathrm{Cu}_{12} \mathrm{O}_{8}\left(\mathrm{AsO}_{4}\right)_{8}\right]^{q-}$ clusters $\left(M=\mathrm{Fe}^{3+}, \mathrm{Ti}^{4+}\right)$ in arsmirandite and lehmannite found in Tolbachik fumaroles provides a useful clue for the targeted synthesis of their analogues under laboratory conditions. As it has been demonstrated previously ${ }^{49-51}$, fumarolic minerals with oxocentered cores can be conveniently synthesized using chemical vapor transport techniques. The occurrence of the $\left[M \subset \mathrm{Cu}_{12} \mathrm{O}_{8}\left(\mathrm{AsO}_{4}\right)_{8}\right]^{q-}$ nanoclusters in Tolbachik fumaroles testifies that they are stable under high temperatures $\left(500-700^{\circ} \mathrm{C}\right)$ at least in the gaseous and crystalline phases and may as well possess interesting physical and chemical properties. They could also play the role of metal transport forms in fumarolic gases, in agreement with the previous proposal ${ }^{52}$ about the similar geochemical role of tetranuclear $\left(\mathrm{OCu}_{4}\right)$ clusters.

The geometrical similarity of the $\mathrm{Na}$ array in arsmirandite and lehmannite to that observed in halite, $\mathrm{NaCl}$, allows to describe both minerals as consisting of cubic-shape nanoclusters periodically integrated into deficient $\mathrm{NaCl}$ matrix, a feature that is quite uncommon for inorganic materials. There has been a recent interest in salt-inclusion compounds (SICs), which possess hierarchical structures consisting of porous metal-oxide frameworks with voids filled with simple ionic salts ${ }^{53}$. The examples of natural SICs are averievite, $\mathrm{Cu}_{5} \mathrm{O}_{2}\left(\mathrm{VO}_{4}\right) \cdot n M \mathrm{Cl}_{x}$ $(M=\mathrm{Cu}, \mathrm{Cs}, \mathrm{Rb}, \mathrm{K})^{54-57}$, and aleutite, $\mathrm{Cu}_{5} \mathrm{O}_{2}\left(\mathrm{AsO}_{4}\right)\left(\mathrm{VO}_{4}\right) \cdot\left(\mathrm{Cu}_{0.5}{ }_{0.5}\right) \mathrm{Cl}^{25}$. In the case of arsmirandite and lehmannite, we have the opposite situation, i.e., the incorporation of metal-oxide clusters into the salt matrix, which, as to our knowledge, had never been observed at least in minerals and mineral phases.

Received: 19 November 2019; Accepted: 24 March 2020;

Published online: 14 April 2020 


\section{References}

1. Pope, M. T. \& Müller, A. Polyoxometalate Chemistry: From Topology via Self-Assembly to Applications (Kluwer Academic Publishers, 2001).

2. Miras et al. Engineering polyoxometalates with emergent properties. Chem. Soc. Rev. 41, 7403-7430 (2012).

3. Miras et al. Polyoxometalate based open frameworks (POM-OFs). Chem. Soc. Rev. 43, 5679-5699 (2014).

4. Nyman, M. \& Burns, P. C. A comprehensive comparison of transition-metal and actinyl polyoxometalates. Chem. Soc. Rev. 41, 7354-7367 (2012).

5. Yang, P. \& Kortz, U. Discovery and evolution of polyoxopalladates. Acc. Chem. Res. 51, 1599-1608 (2018).

6. Müller, A. et al. Topologically interesting cages for negative ions with extremely high "coordination number" - an unusual property of V-O clusters. Angew. Chem. Int. Ed. 29, 926-927 (1990).

7. Kipka, R. \& Muller-Buschbaum, H. Über Oxocuprate, XXI. Bariumoxohalogenocuprate(II) mit Strukturbeziehungen zu BaCuO . Z. Naturforsch. 32b, 124-126 (1977).

8. Kondinski, A. \& Monakhov, K. Y. Breaking the Gordian Knot in the Structural Chemistry of Polyoxometalates: Copper(II)-Oxo/ Hydroxo Clusters. Chem. Eur. J. 23, 7841-7852 (2017).

9. Kampf, A. R. et al. The heteropolymolybdate family: Structural relations, nomenclature scheme and new species. Mineral. Mag. 76, 1175-1207 (2012).

10. Kampf, A. R. et al. Ammoniolasalite, $\left[\left(\mathrm{NH}_{4}\right)_{2} \mathrm{Mg}_{2}\left(\mathrm{H}_{2} \mathrm{O}\right)_{20}\right]\left[\mathrm{V}_{10} \mathrm{O}_{28}\right]$, a new decavanadate species from the Burro mine, Slick Rock district. Colorado. Can. Mineral. 56, 859-869 (2018).

11. Cooper, M. A. et al. Determination of $\mathrm{V}^{4+}: \mathrm{V}^{5+}$ ratios in the $\left[\mathrm{V}_{10} \mathrm{O}_{28}\right]^{\mathrm{n}-}$ decavanadate polyanion. Can. Mineral. 57, 235-244 (2019).

12. Cooper, M. A. et al. Identifying protonated decavanadate polyanions. Can. Mineral. 57, 245-253 (2019).

13. Friis, H. et al. Peterandresenite, $\mathrm{Mn}_{4} \mathrm{Nb}_{6} \mathrm{O}_{19} \cdot 14 \mathrm{H}_{2} \mathrm{O}$, a new mineral containing the Lindqvist ion from a syenite pegmatite of the Larvik Plutonic Complex, southern Norway. Eur. J. Miner. 26, 567-576 (2014).

14. Olds, T. A. et al. Ewingite: Earth's most complex mineral. Geology 45, 1007-1010 (2017).

15. Olds, T. A. et al. Paddlewheelite, a new uranyl carbonate from the Jáchymov district, Bohemia, Czech Republic. Minerals 8, 511 (2018).

16. Brugger, J. et al. Mineralogy and crystal structure of bouazzerite from Bou Azzer, Anti-Atlas, Morocco: Bi-As-Fe nanoclusters containing $\mathrm{Fe}^{3+}$ in trigonal prismatic coordination. Amer. Mineral. 92, 1630-1639 (2007).

17. Pekov, I. V. et al. Whitecapsite, a new hydrous iron and trivalent antimony arsenate mineral from the White Caps mine, Nevada, USA. Eur. J. Mineral. 26, 577-587 (2014).

18. Effenberger, H., Giester, G., Krause, W. \& Bernhardt, H. J. Tschörtnerite, a copper-bearing zeolite from the Bellberg volcano, Eifel, Germany. Amer. Mineral. 83, 607-617 (1998).

19. Cooper, M. A. \& Hawthorne, F. C. Boleite: revision of the formula, $\mathrm{KPb}_{26} \mathrm{Ag}_{9} \mathrm{Cu}_{24} \mathrm{Cl}_{62}(\mathrm{OH})_{48}$. Can. Mineral. 38, 801-808 (2000).

20. Giuseppetti, G. et al. The crystal structure of pseudoboleite: $\mathrm{Pb}_{31} \mathrm{Cu}_{24} \mathrm{Cl}_{62}(\mathrm{OH})_{48}$; its relations with the structures of boleite and cumengeite. N. Jb. Mineral., Mh. 1992, 113-126 (1992).

21. Cruciani, G. et al. First Italian occurrence of cumengéite from Vesuvio: crystal structure refinement and revision of the chemical formula. Mineral. Mag. 69, 1037-1045 (2005).

22. Pekov, I. V. et al. Copper minerals from volcanic exhalations - a unique family of natural compounds: crystal-chemical review. Acta Crystallogr. B74, 502-518 (2018).

23. Pekov, I. V. et al. New arsenate minerals from the Arsenatnaya fumarole, Tolbachik volcano, Kamchatka, Russia. X. Edtollite, $\mathrm{K}_{2} \mathrm{NaCu}_{5} \mathrm{Fe}^{3+} \mathrm{O}_{2}\left(\mathrm{AsO}_{4}\right)_{4}$, and alumoedtollite, $\mathrm{K}_{2} \mathrm{NaCu}_{5} \mathrm{AlO}_{2}\left(\mathrm{AsO}_{4}\right)_{4}$. Mineral. Mag. 83, 485-495 (2019).

24. Pekov, I. V. et al. New arsenate minerals from the Arsenatnaya fumarole, Tolbachik volcano, Kamchatka, Russia. XII. Zubkovaite, $\mathrm{Ca}_{3} \mathrm{Cu}_{3}\left(\mathrm{AsO}_{4}\right)_{4}$. Mineral. Mag. 83, in press. https://doi.org/10.1180/mgm.2019.33.

25. Siidra, O. I. et al. Aleutite $\left[\mathrm{Cu}_{5} \mathrm{O}_{2}\right]\left(\mathrm{AsO}_{4}\right)\left(\mathrm{VO}_{4}\right) \cdot\left(\mathrm{Cu}_{0.5} \square_{0.5}\right) \mathrm{Cl}$, a new complex salt-inclusion mineral with $\mathrm{Cu}^{2+}$ substructure derived from Kagome-net. Mineral. Mag., 83, in press. https://doi.org/10.1180/mgm.2019.42.

26. Siidra, O. et al. Dokuchaevite, $\mathrm{Cu}_{8} \mathrm{O}_{2}\left(\mathrm{VO}_{4}\right)_{3} \mathrm{Cl}_{3}$, a new mineral with remarkably diverse Cu${ }^{2+}$ mixed-ligand coordination environments. Mineral. Mag. 83, 749-755 (2019).

27. Krivovichev, S. V. et al. Anion-centered tetrahedra in inorganic compounds. Chem. Rev. 113, 6459-6535 (2013).

28. Krivovichev, S. V. Structure description, interpretation and classification in mineralogical crystallography. Crystallogr. Rev. 23, 2-71 (2017).

29. Pekov, I. V. et al. New arsenate minerals from the Arsenatnaya fumarole, Tolbachik volcano, Kamchatka, Russia. I. Yurmarinite, $\mathrm{Na}_{7}\left(\mathrm{Fe}^{3+}, \mathrm{Mg}, \mathrm{Cu}\right)_{4}\left(\mathrm{AsO}_{4}\right)_{6}$. Mineral. Mag. 78, 905-917 (2014).

30. Pekov, I. V. et al. Fumarolic arsenates - a special type of arsenic mineralization. Eur. J. Mineral. 30, 305-322 (2018).

31. Blackwell, L. J. et al. Crystal structure of anhydrous nitrates and their complexes. Part VII. 1.5 Dinitrogen tetroxide solvate of iron (III) nitrate. J. Chem. Soc. Dalton Trans. 20, 2068-2072 (1975).

32. King, T. J. et al. Eight-coordinate iron(III) complex: crystal structure of tetraphenylarsonium tetranitroferrate(III). J. Chem. Soc. D: Chem. Comm. 11, 554 (1971).

33. Garner, C. D. \& Wallwork, S. C. The crystal structures of anhydrous nitrates and their complexes. Part III. Titanium(IV) nitrate. J. Chem. Soc. A: Inorg. Phys. Theor. 1969, 1496-1500 (1969).

34. Fourati, M. et al. A strongly chelating bindentate $\mathrm{ClO}_{4}$. New synthesis route and crystal structure determination of Ti $\left(\mathrm{ClO}_{4}\right)_{4}$. Inorg. Chem. 25, 1386-1390 (1986).

35. Krivovichev, S. V. et al. "Face-to-face" relationships between oxocentered tetrahedra and cation-centered tetrahedral oxyanions in crystal structures of minerals and inorganic compounds. Mineral. Mag. 63, 263-266 (1999).

36. Abrahams, S. \& Bernstein, J. Accuracy of an automatic diffractometer. Measurement of the sodium chloride structure factors. Acta Crystallogr. 18, 926-932 (1965).

37. Li, Y. et al. Crystal chemistry of lead oxide hydroxide nitrates. II. The crystal structure of $\mathrm{Pb}_{13} \mathrm{O}_{8}(\mathrm{OH})_{6}\left(\mathrm{NO}_{3}\right)_{4}$. J. Solid State Chem. 158, 74-77 (2001).

38. Kolitsch, U. \& Tillmanns, E. The crystal structure of anthropogenic $\mathrm{Pb}_{2}(\mathrm{OH})_{3}\left(\mathrm{NO}_{3}\right)$, and a review of $\mathrm{Pb}-(\mathrm{O}, \mathrm{OH})$ clusters and lead nitrates. Mineral. Mag. 67, 79-93 (2003).

39. Wang, G. et al. Series of lead oxide hydroxide nitrates obtained by adjusting the $\mathrm{pH}$ values of the reaction systems. Inorg. Chem. $\mathbf{5 3}$, $5222-5228$ (2014).

40. Chubarova, E. V. et al. Self-assembly of a heteropolyoxopalladate nanocube: $\left[\mathrm{Pd}^{\mathrm{II}}{ }_{13} \mathrm{AsV}_{8} \mathrm{O}_{34}(\mathrm{OH})_{6}\right]^{8-}$. Angew. Chem. Int. Ed. 47, 9542-9546 (2008).

41. Barsukova-Stuckart, M. et al. 3d metal ions in highly unusual eight-coordination: the phosphate-capped dodecapalladate(II) nanocube. Chem. Eur. J. 18, 6167-6171 (2012).

42. Barsukova-Stuckart, M. et al. Polyoxopalladates encapsulating 8-coordinated metal ions, $\left[\mathrm{MO}_{8} \mathrm{Pd}^{\mathrm{II}}{ }_{12} \mathrm{~L}_{8}\right]^{\mathrm{n}-}\left(\mathrm{M}^{2}=\mathrm{Sc}^{3+}, \mathrm{Mn}^{2+}, \mathrm{Fe}^{3+}\right.$, $\mathrm{Co}^{2+}, \mathrm{Ni}^{2+}, \mathrm{Cu}^{2+}, \mathrm{Zn}^{2+}, \mathrm{Lu}^{3+} ; \mathrm{L}=\mathrm{PhAsO}_{3}{ }^{2-}, \mathrm{PhPO}_{3}{ }^{2-}, \mathrm{SeO}_{3}{ }^{2-}$ ). Inorg. Chem. 51, 13214-13228 (2012).

43. Lin, Z.-G. et al. Cation-induced synthesis of new polyoxopalladates. Inorg. Chem. 51, 4435-4437 (2012).

44. Lin, Z.-G. et al. Controlled synthesis of polyoxopalladates, and their gas-phase fragmentation study by electrospray ionization tandem mass-spectrometry. Eur. J. Inorg. Chem. 2013, 3458-3463 (2013).

45. Izarova, N. V. et al. The mixed gold-palladium polyoxo-noble-metalate, $\left[\mathrm{NaAu}^{\mathrm{III}}{ }_{4} \mathrm{Pd}^{\mathrm{II}}{ }_{8} \mathrm{O}_{8}\left(\mathrm{AsO}_{4}\right)_{8}\right]^{11-}$. Chem. Eur. J. 20, 8556-8560 (2014). 
46. Barsukova, M. et al. Polyoxopalladates encapsulating yttrium and lanthanide ions, $\left[\mathrm{X}^{\mathrm{III}} \mathrm{Pd}_{12}^{\mathrm{II}}(\mathrm{AsPh})_{8} \mathrm{O}_{32}\right]^{5-}(\mathrm{X}=\mathrm{Y}, \mathrm{Pr}, \mathrm{Nd}, \mathrm{Sm}, \mathrm{Eu}$, Gd, Tb, Dy, Ho, Er, Tm, Yb, Lu). Chem. Eur. J. 16, 9076-9085 (2010).

47. Yang, P. et al. Tetravalent metal ion guests in polyoxopalladate chemistry: synthesis and anticancer activity of $\left[\mathrm{MO}_{8} \mathrm{Pd}_{12}\left(\mathrm{PO}_{4}\right)_{8}\right]^{12-}$ $\left(\mathrm{M}=\mathrm{Sn}^{\mathrm{IV}}, \mathrm{Pb}^{\mathrm{IV}}\right)$. Inorg. Chem. 58, 11294-11299 (2019).

48. Bhattacharya, S. et al. Discovery of polyoxo-noble-metalate-based metal-organic frameworks. J. Amer. Chem. Soc. 141, 3385-3389 (2019).

49. Kovrugin, V. M. et al. Emulating exhalative chemistry: synthesis and structural characterization of ilinskite, $\mathrm{Na}_{2}\left[\mathrm{Cu}_{5} \mathrm{O}_{2}\right]\left(\mathrm{SeO}_{3}\right)_{2} \mathrm{Cl}_{3}$, and its K-analogue. Mineral. Petrol. 109, 421-430 (2015).

50. Kovrugin, V. M. et al. Oxocentered $\mathrm{Cu}(\mathrm{II})$ lead selenite honeycomb lattices hosting $\mathrm{Cu}(\mathrm{I}) \mathrm{Cl}_{2}$ groups obtained by chemical vapor transport reactions. Chem. Comm. 51, 9563-9566 (2015).

51. Kornyakov, I. V. et al. Oxocentered units in three novel Rb-containing copper compounds prepared by CVT reaction method. Z. Anorg. Allg. Chem. 644, 77-81 (2018).

52. Filatov, S. K. et al. Types of polymerization of $\left[\mathrm{OCu}_{4}\right]^{6+}$ tetrahedra in compounds with 'additional' oxygen atoms. Dokl. AN SSSR 322, 536-539 (1992).

53. Moore, E. E. et al. Understanding the stability of salt-inclusion phases for nuclear waste-forms through volume-based thermodynamics. Sci. Rep. 8, 15294 (2018)

54. Vergasova, L. P. et al. Averievite $\mathrm{Cu}_{5}\left(\mathrm{VO}_{4}\right)_{2} \mathrm{O}_{2} \cdot \mathrm{nMX}$ - a new mineral of volcanic exhalations. Dokl. Akad. Nauk 359, $804-807$ (1998).

55. Krivovichev, S. V. et al. Refinement of the crystal structure of averievite $\mathrm{Cu}_{5} \mathrm{O}_{2}\left(\mathrm{VO}_{4}\right) \cdot \mathrm{nMCl}_{\mathrm{x}}(\mathrm{M}=\mathrm{Cu}, \mathrm{Cs}, \mathrm{Rb}, \mathrm{K})$. Zap. Ross. Mineral. Obshch. 144, 101-109 (2015).

56. Botana, A. S. et al. Averievite: a copper oxide kagome antiferromagnet. Phys. Rev. B 98, 054421 (2018).

57. Volkova, L. M. \& Marinin, D. V. Antiferromagnetic spin-frustrated layers of corner-sharing $\mathrm{Cu}_{4}$ tetrahedra on the kagome lattice in volcanic minerals $\mathrm{Cu}_{5} \mathrm{O}_{2}\left(\mathrm{VO}_{4}\right)_{2}(\mathrm{CuCl}), \mathrm{NaCu}_{5} \mathrm{O}_{2}\left(\mathrm{SeO}_{3}\right)_{2} \mathrm{Cl}_{3}$, and $\mathrm{K}_{2} \mathrm{Cu}_{5} \mathrm{Cl}_{8}(\mathrm{OH})_{4} \bullet 2 \mathrm{H}_{2} \mathrm{O}$. J. Phys. Cond. Matt. 30, 425801 (2018).

\section{Acknowledgements}

This study was supported by the Russian Science Foundation, grant no. 19-17-00050. The technical support by the St. Petersburg State University X-Ray Diffraction Resource Center and Center for Physical Methods of Surface Investigation is acknowledged.

\section{Author contributions}

I.V.P., A.G.T. and E.G.S. collected the samples and performed detailed mineralogical study; chemical characterization was carried out by V.O.Y. and N.N.K.; S.N.B. collected X-ray diffraction data and solved the crystal structures; S.V.K. refined the crystal structure models and proposed their interpretation; J.G. measured and interpreted XANES spectra; S.N.B., S.V.K. and I.V.P together wrote the manuscript.

\section{Competing interests}

The authors declare no competing interests.

\section{Additional information}

Supplementary information is available for this paper at https://doi.org/10.1038/s41598-020-63109-1.

Correspondence and requests for materials should be addressed to S.V.K.

Reprints and permissions information is available at www.nature.com/reprints.

Publisher's note Springer Nature remains neutral with regard to jurisdictional claims in published maps and institutional affiliations.

Open Access This article is licensed under a Creative Commons Attribution 4.0 International License, which permits use, sharing, adaptation, distribution and reproduction in any medium or format, as long as you give appropriate credit to the original author(s) and the source, provide a link to the Creative Commons license, and indicate if changes were made. The images or other third party material in this article are included in the article's Creative Commons license, unless indicated otherwise in a credit line to the material. If material is not included in the article's Creative Commons license and your intended use is not permitted by statutory regulation or exceeds the permitted use, you will need to obtain permission directly from the copyright holder. To view a copy of this license, visit http://creativecommons.org/licenses/by/4.0/.

(C) The Author(s) 2020 